\section{9 非炎症性伝音難聴の手術成績}

○松元一郎, 㷊沙保宮医大)

林田邦彦, 南立昌幸, 德永 悠（九大）

非炎症伝音難䏇は最近とみに增加の傾向にある。今

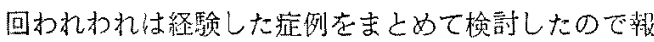
告する。

症例はいずれ毛外耳道䦥塞を伴なう症例を除外して 主に耳小骨連鎖奇非，耳硬化症 VAN DER HOEVE 症 候群および外賃性の症例について速銷の修復法々, 術 後成績を检討してるた。

耳小骨連鎖奇形に対しては自家骨の interposition 法, ビニール管, テフロンピストン，プラチ小 テフロンピストンなどの人工物による修復を試みた。

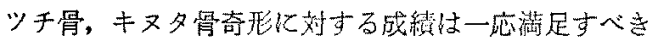
成績を得た。アブミ骨奇现に対しては Stapedectoー my を原則として施行し，テフロンピストン，プラチ ナテフロンピストンを用い，前庭䓡には筋榄，静眽 片, Gelfoam 神用した。

前庭空の欠損した症例は最も修得に困難なものであ る.開空乞の屯のに成功しな加つた例，開空不充分 であつた例，充分開㤎它行い得た例について手術成繳 を検討したが，開空の大きさは $1.0 \times 1.5 \mathrm{~mm}$ 以上 が望ましいのではないかと考元られた。

耳硬化症, VAN DER HOEVE 症候群佂対しては Stapedectomy 党行つた。こ机らの症例の中で失敗 に終つた例としては次のどとくである。

1 例は足板が obliterative で充分な開空が得ら机 なかつた。1例は鼓模㹬孔をきたして感染し，1例は 抗生物質の使用加不充分であつたため的共に内耳障害 をきたした，1例は術徭のめまい症状が持続し，high tone loss 党きたした症例である。

一般に日本人に㧍ける耳硬化症では典型的な Otospongiosis 孝認めることは少ない上うに思和机た。

外䇰性伝音難㯖の修復は比較的に容易であり，術後 成縝も满足出来る結果か得られた。連銷の蜼断はキ又

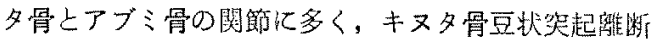
例やアブミ骨が倒れて浮上した状態にある痱例老経揭 した.

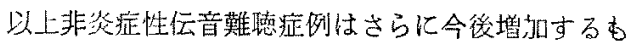
のと䍐われる，穴の修復には常に細心の注意と充分な 経䮖加要求されるが成功した場合の喼者への恩恵は絶 大なあのがあり，ますますその手術成績の向上のため の努力が払加れなければならない。
110 伝音系奇形耳の聴力改善手㣫 一最近の統計的観察—

\author{
○增四 游, 松原 浄, 藤本明子 \\ 小朴正尚，小含義郎（岡山大） \\ 归中 微 (岡山赤十宇病院)
}

目的およひ左法：1955 年以来当科で行つてきた伝 音系奇形耳住刘す恥力改善手術施行例計 145 耳の中 耳所見, 各手術方法上手術成繢について, 統計的飞観 察した。また，とくに最近の手衍症例は中心に,アブ ミ骨奇形を中心とした中耳所見と手術方法の適応につ いて, 胎生学的な考察む加えて梠討した。

対象は，1974年 3 月までに施衡した，外耳道閉銷 症例 63 耳, 外耳道诙小例 27 耳, お上び, 外耳道正常 列 34 耳の計 124 耳之, 方の後 1976 年 12 月まで 2 年 8 力月間任施術した，外耳道閔鎖症例 14 耳, 外耳 道㹨小例 3 耳, 外耳道正常例 4 耳の計 21 耳である。

成 績：とくに術後の衈力改善についてみると, 会 詰音域での平均気学㯖力が $40 \mathrm{~dB}$ 以内のおのを成功 例上すれば, 1974 年 3 月までの統計では, 内敢開空 術 $79.2 \%$, 鼓室成形術 $45.5 \%$ ，アブミ骨手術 37.5

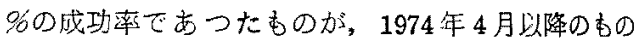
では，症例数は少ないがそれぞれ，83.3\%，83.3\%， アブミ骨手術では1例に行つててれが成功例となつて いる。いずれにせよ，全般的に成果の改善がみられて いる.

一方，中耳所見についてみると，手術成績に直結し た卵门空部とくにアブミ骨に対する钼察が重要である が, 最近の 21 耳中, 卵䈍部確認例は 14 耳であり， そのうちアブミ骨正常で不動のもの10耳, 奇形のも の2耳，欠除しているもの 2 耳であつだ。やはりアブ ミ骨翼常例の多いと之が注目される。

考按亡結論：以上の結果について考えると, 前の 統計加大变長期にわたる遠隔成嚗によついるとと，最 近に比へて藻物療法や術後骖断, 手術器具や材料など 多くの点で差裢があつたことも，最近の統計との相遼

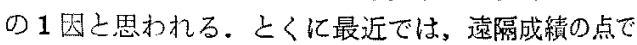
問題はあるものの，アブミ骨手術，鼓室成形術飞関す る諸点の進步改善も見逃せない.

加加る観点から，最近経験した鼓室成形術拈よび ブミ骨手術施行の具体例についても検討し，てれら手 術方法が症例を選べばきわぬて有効であるとと,内耳

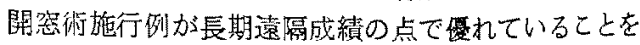
結論としてのべた。 